\title{
PENGARUH INTELLECTUAL CAPITAL, FINANCING TO DEPOSIT RATIO DAN NON PERFORMING FINANCING TERHADAP PROFITABILITAS PERBANKAN SYARIAH DI INDONESIA
}

\author{
Fakhri Hatta ${ }^{1}$, Fauziah Aida Fitri ${ }^{* 2}$ \\ ${ }^{1,2}$ Program Studi Akuntansi Fakultas Ekonomi dan Bisnis Universitas Syiah Kuala \\ e-mail: fakhri.hatta96@gmail.com ${ }^{1}$, fauziah.afitri@ unsyiah.ac.id ${ }^{2}$ \\ * Corresponding Author
}

\begin{abstract}
Abstrak
This research aims to investigate the influence of Intellectual capital, Financing to deposit ratio and Non performing financing on profitability of Islamic Banking in Indonesia. The analysis technique used in this study is the multiple linear regression analysis. The type of data employed is secondary data from financial statements of each banks. The results of this research indicate that (1) Intellectual capital, Financing to deposit ratio and Non performing financing simultaneously effect on profitability (2) Intellectual capital has no significant effect on profitability (3) Financing to deposit ratio has significant effect on profitability and (4) Non performing financing has significant effect on profitability of Islamic Banking in Indonesia
\end{abstract}

Keywords: Profitability, Islamic Banking, Intellectual capital, Financing to deposit ratio, Non performing financing

\section{Pendahuluan}

Tumbuh kembang keuangan syariah di Indonesia sangatlah menjanjikan, aset perbankan syariah Indonesia berada di peringkat ke-9 terbesar secara global mencapai US $\$ 28,08$ miliar. Berdasarkan Global Islamic Finance Report 2017, aset keuangan syariah menempati peringkat ke-10 secara global, mencapai US\$66 miliar, dan Islamic Finance Country Index meningkat ke posisi 6 pada 2018, dari posisi 7 pada 2017. (www.bi.go.id)

Fenomena pesatnya pekembangan keuangan syariah tersebut dibahas dalam The 3rd International Conference on Indonesian Economy and Development dan The 1st International Conference on Islamic Economics, Business and Finance yang mengangkat tema Enhancing Islamic Economics, Business and Finance: Towards the Real Economy and Sustainable Development di Jakarta mengatakan bahwa, pengembangan ekonomi keuangan syariah dibutuhkan untuk memperkuat struktur ekonomi dan pasar keuangan dalam mendukung pertumbuhan ekonomi yang berkelanjutan. Hal ini dilandaskan pada potensi pengembangan ekonomi dan keuangan syariah yang cukup menjanjikan. Pengembangan ekonomi dan keuangan syariah diharapkan menjadi salah satu upaya dalam memperkuat struktur ekonomi dan pasar keuangan global saat ini dan mendatang" (www.liputan6.com, 2018). Merujuk pada pesatnya pertumbuhan perbankan syariah dewasa ini, maka analisis diperlukan untuk melihat sejauh mana perbankan syariah di Indonesia dapat berkembang. Hal ini dapat dilakukan dengan menganalisa laporan keuangan pada bank syariah tersebut, salah satunya yaitu menganalisa tingkat profitabilitasnya (Bustamam \& Aditia, 2016).

Abdul Halim dkk (2016) mengungkapkan bahwa, Profitabilitas merupakan suatu ukuran yang digunakan untuk menilai sejauh mana perusahaan mampu menghasilkan laba pada tingkat yang diterima. Perusahaan sebagai salah satu bentuk organisasi pada umumnya memiliki tujuan untuk mencapai laba atau keuntungan secara maksimal. Profitabilitas dapat mempengaruhi pertumbuhan dan perkembangan perusahaan melalui aset yang dimiliki. Semakin tinggi tingkat profitabilitas suatu perusahaan maka akan semakin tinggi pula peningkatan aset perusahaan tersebut, sehingga akan berdampak terhadap pertumbuhan perusahaan.

ROA akan digunakan untuk mengukur profitabilitas pada penelitian ini dikarenakan ROA 
lebih memfokuskan pada kemampuan perusahaan perbankan untuk memperoleh profit dalam kegiatan perusahaan perbankan secara keseluruhan. Selain itu, untuk menentukan tingkat kesehatan suatu bank, Bank Indonesia lebih mementingkan penilaian ROA daripada ROE karena Bank Indonesia lebih mengutamakan nilai profitabilitas suatu bank yang diukur dengan aset yang dananya sebagian besar berasal dari dana simpanan masyarakat sehingga ROA lebih mewakili dalam mengukur tingkat profitabilitas perbankan sedangkan Return on Equity (ROE) hanya mengukur return yang diperoleh dari investasi pemilik perusahaan perbankan dalam bisnis tersebut (Dendawijaya, 2005:29).

Diantara faktor-faktor yang mempengaruhi profitabilitas adalah intellectual capital. Intellectual capital merupakan suatu aset tidak berwujud dengan kemampuan memberi nilai kepada perusahaan dan masyarakat meliputi paten, hak atas kekayaan intelektual, hak cipta dan waralaba. Intellectual capital juga dapat dipandang sebagai pengetahuan dan pengalaman yang dapat digunakan untuk menciptakan kekayaan. Intellectual capital tidak hanya berupa goodwill ataupun paten seperti yang sering dilaporkan dalam neraca. Kompetensi karyawan, hubungan dengan pelanggan, penciptaan inovasi, sistem komputer dan administrasi, hingga kemampuan atas penguasaan teknologi juga merupakan bagian dari intellectual capital (Soetedjo dan Mursida, 2014).

Rasio keuangan seperti financing to deposit ratio (FDR) dan non performing financing (NPF) juga termasuk dalam faktor-faktor yang mempengaruhi profitabilitas. Untuk dapat mengetahui keadaan finansial bank pada saat ini, masa lalu maupun memproyeksikan kondisi bank di masa mendatang dapat dilakukan dengan analisis rasio keuangan. Analisis rasio merupakan suatu cara yang umum digunakan untuk menganalisis laporan keuangan, sedangkan rasio merupakan alat ukur yang digunakan untuk menggambarkan hubungan antara jumlah tertentu dengan jumlah yang lain, rasio dapat dinyatakan dalam bentuk relative maupun absolut (Sangia, 2012).

FDR adalah rasio pembiayaan antara dana yang dihimpun oleh bank dan dana yang dijadikan pembiayaan. Financing to deposit ratio (FDR) digunakan oleh bank syariah sedangkan bank konvensional menggunakan istilah loan to deposit ratio (LDR) (Wardana \& Widyarti, 2015). Peraturan Bank Indonesia nomor: 12/19/pbi/2010 tentang giro wajib minimum bank umum pada bank Indonesia dalam rupiah dan valuta asing menyebutkan bahwa batas bawah LDR sebesar 78\% dan batas atas LDR sebesar 100\% (www.ojk.go.id, 2019)

Adapun faktor lain yang diprediksi mempengaruhi profitabilitas ialah non performing financing (NPF). NPF merupakan rasio pembiayaan yang macet, hal ini dapat disebabkan karena nasabah yang menerima pembiayaan mengalami kerugian atau kebangkrutan sehingga pembiayaan yang diberikan oleh bank tidak dapat dikembalikan. Semakin tinggi rasio NPF maka dapat menyebabkan berkurangnya laba yang dapat dihasilkan. Hal ini disebabkan oleh meningkatnya biaya yang dikeluarkan bank yaitu biaya pencadangan aktiva produktif yang dibutuhkan menjadi lebih tinggi. Sebaliknya semakin rendah rasio NPF maka akan berdampak positif terhadap laba yang dihasilkan oleh bank (Rivai, 2010).

\section{Kerangka Teoretis dan Pengembangan Hipotesis \\ Pengaruh Intellectual capital Terhadap Profitabilitas}

Perkembangan dan pertumbuhan perbankan di Indonesia yang sangat cepat juga memberikan dampak yang sangat besar terhadap persaingan antar bank. Untuk menghadapi persaingan yang sangat keras, terdapat banyak cara yang dapat dilakukan oleh bank yaitu dengan keunggulan kompetitif (competitive advantage). Keunggulan ini dapat dibentuk dengan berbagai cara seperti menciptakan produk dengan desain yang baru, penggunaan teknologi modern, desain organisasi, serta menggunakan sumber daya yang ada dengan efektif, efisien dan ekonomis (Sheleen, 2015). Faktor-faktor tersebut termasuk ke dalam intellectual capital.

Menurut Puspitasari (2011), intellectual capital adalah ilmu pengetahuan atau daya pikir yang dimiliki oleh perusahaan, tidak memiliki bentuk fisik (tidak berwujud), dan dengan adanya modal intellektual tersebut, perusahaan akan mendapatkan tambahan keuntungan atau kemapanan proses usaha serta memberikan perusahaan suatu nilai lebih dibanding dengan kompetitor atau perusahaan lain.

Ada beberapa penelitian terdahulu yang 
meneliti bagaimana pengaruh intellectual capital pada profitabilitas. Penelitian yang telah dilakukan oleh Abdul Halim dkk., (2016); Bustamam dan Dhenni Aditia (2016); Tuffahati Dhiagriya Kuspinta dan Achmad Husaini (2018) menyimpulkan bahwa intellectual capital memiliki pengaruh positif dan signifikan terhadap profitabilitas. Semakin tinggi tingkat intellectual capital sebuah perusahaan, maka semain tinggi pula profitabilitasnya. Meskipun demikian, ada beberapa hasil penelitian yang menunjukkan bahwa intellectual capital tidak memiliki pengaruh terhadap profitabilitas, seperti penelitian yang dilakukan oleh Basuki dan Sianipar (2009), Firrer dan Williams (2003) dalam Bustamamam, Dhenni Aditia (2016) dan Ulfa Ikhwazahmi (2014).

\section{Pengaruh Financing to deposit ratio Terhadap Profitabilitas}

Financing to deposit ratio adalah rasio seluruh jumlah pembiayaan yang diberikan bank dengan dana yang diterima oleh bank. Jika rasio tersebut semakin tinggi maka memberikan indikasi semakin rendahnya kemampuan likuiditas bank yang bersangkutan. Berkurangnya tingkat likuiditas dapat memberikan dampak terhadap naiknya profitabilitas. Jadi FDR memberikan pengaruh positif terhadap tingkat profitabilitas. Karena dengan tingginya FDR maka penyaluran dana untuk pembiayaan semakin besar (Almunawwaroh \& Marliana, 2018).

Nilai FDR juga menunjukkan efektif tidaknya bank dalam menyalurkan pembiayaan, apabila nilai FDR menunjukkan persentase terlalu tinggi maupun terlalu rendah maka bank dinilai tidak efektif dalam menghimpun dan menyalurkan dana yang diperoleh dari nasabah, sehingga mempengaruhi laba yang didapat. Arah hubungan yang timbul antara FDR terhadap ROA adalah positif, karena apabila bank mampu menyediakan dana dan menyalurkan dana kepada nasabah maka akan meningkatkan return yang didapat dan berpengaruh kepada meningkatnya ROA yang didapat oleh bank syariah (Riyadi F. Slamet \& Agung, 2014).

Penelitian tentang FDR yang diteliti Slamet Riyadi, Agung Yulianto (2014); Dhian Dayinta (2012) dan Medina Almunawwaroh, Rina Marliana (2018) menyimpulkan bahwa "FDR berpengaruh terhadap profitabilitas. Sedangkan hasil penelitian yang dilakukan oleh Ridhlo Ilham Putra Wardana, Endang Tri Widyarti (2015) dan Jaka Sriyana (2014) menunjukkan tidak adanya pengaruh antara FDR terhadap profitabilitas.

\section{Pengaruh Non performing financing Terhadap Profitabilitas}

Non performing financing merupakan tingkat risiko yang dihadapi bank. NPF adalah jumlah pembiayaan yang bermasalah dan ada kemungkinan tidak dapat ditagih. Sesuai dengan aturan yang telah ditetapkan oleh Bank Indonesia, besarnya NPF yang baik adalah dibawah 5\%. NPF diukur dari rasio perbandingan antara kredit bermasalah terhadap total kredit yang diberikan. Semakin besar NPF akan memperkecil keuntungan/profitabilitas bank karena dana yang tidak dapat ditagih mengakibatkan bank tidak dapat melakukan pembiayaan pada aktiva produktif lainnya. Hal ini mengakibatkan pendapatan bank menjadi berkurang sehingga profitabiltas perbankan akan terganggu (Almunawwaroh \& Marliana, 2018).

Menurut Mahmoedin (2010) dalam bukunya menyebutkan bahwa "suatu pembiayaan yang mengalami masalah biasanya dikarenakan oleh faktor eksternal pihak nasabah maupun internal dari bank itu sendiri Faktor-faktor internal diantaranya meliputi kebijakan dari pihak bank dalam pemberian pembiayaan yang terlalu ekspansif,lemahnya sistem administrasi dan pengawasan pembiayaan,serta lemahnya sistem informasi pembiayaan. Sedangkan untuk faktor eksternal penyebabnya adalah kegagalan usaha debitor,menurunnya kegiatan ekonomi dan musibah yang terjadi pada usaha debitur/kegiatan usahanya.

Penelitian mengenai Non performing financing (NPF) yang dialakukan Medina Almunawwaroh, Rina Marliana (2018), Wahyu Dwi Yulihapsari, Dien Noviany Rahmatika dan Jaka Waskito (2017) menunjukkan bahwa NPF berpengaruh terhadap profitabilitas. Hal ini bertentangan dengan hasil penelitian yang dilakukan oleh Slamet Riyadi, Agung Yulianto (2014) dan Ridhlo Ilham Putra Wardana, Endang Tri Widyarti (2015) yang menunjukkan bahwa NPF tidak memiliki pengaruh yang signifikan terhadap profitabilitas. 
Berdasarkan fenomena dan kejadian yang dijelaskan sebelumnya maka dapat dibuat skema kerangka pemikiran seperti berikut

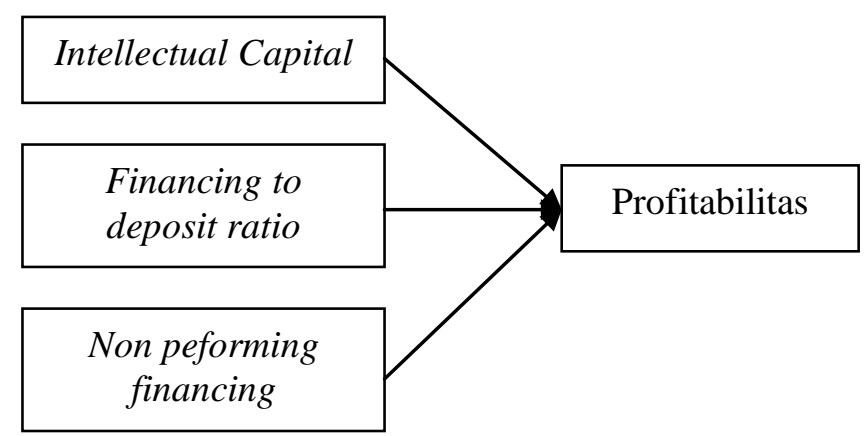

\section{Gambar 1 Kerangka Pemikiran}

\section{Hipotesis}

Berdasarkan kerangka teoritis diatas, maka dapat diformulasikan hipotesis sebagai berikut

$\mathrm{H} 1:$ Intellectual capital, financing to deposit ratio, dan non performing financing secara simultan berpengaruh terhadap profitabilitas perbankan syariah.

$\mathrm{H} 2$ : Intellectual capital berpengaruh terhadap profitabilitas perbankan syariah.

H3: Financing to deposit ratio berpengaruh terhadap profitabilitas perbankan syariah.
H4: Non performing financing berpengaruh terhadap profitabilitas perbankan syariah.

\section{Metode Penelitian \\ Populasi Sampel}

Populasi pada penelitian ini ialah Bank Umum Syariah di Indonesia tahun 2014 sampai dengan tahun 2018. Metode sensus digunakan dalam penelitian ini. Metode sensus merupakan salah satu bentuk pengumpulan data dengan cara mengumpulkan informasi-informasi dari seluruh unit populasi yang berhubungan dan yang terdapat dalam populasi, sehingga semua Bank Umum Syariah di Indonesia dari tahun 2014-2018 digunakan sebagai objek penelitian kecuali Bank BPD Nusa Tenggara Barat Syariah dikarenakan bank tersebut baru konversi menjadi syariah pada akhir tahun 2018.

\section{Tabel 1}

\section{Penentuan Sample Penelitian}

\begin{tabular}{|l|c|}
\hline $\begin{array}{l}\text { Bank umum syariah yang menerbitkan laporan } \\
\text { tahunan berturut-turut selama periode 2014-2018 } \\
(12 \times 5 \text { tahun })\end{array}$ & 60 \\
\hline Bank Aceh Syariah 2017-2018 (1x 2 tahun) & 2 \\
\hline Total & 62 \\
\hline
\end{tabular}

Sumber: Data diolah 2019

\section{Pengukuran Variabel}

Tabel 2

Pengukuran Variabel

\begin{tabular}{|c|l|c|c|}
\hline No & \multicolumn{1}{|c|}{ Variabel } & Pengukuran & Skala \\
\hline 1 & Profitabilitas (ROA) & ROA = -------------- x 100\% & Rasio \\
\hline 2 & Intellectual Capital (IC) & iB-VA = Output - Input & Rasio \\
& & iB-VACA = VA/CE & \\
& & iB-VAHU - VA/HC & \\
& & iB-STVA = SC/VA & \\
\hline 3 & Financing to deposit ratio (FDR) & iB-VAIC $=$ VACA + VAHU + STVA & Rasio \\
\hline 4 & Non Peforming Financing (NPF) & FDR = --------------- x 100\% & Rasio \\
\hline
\end{tabular}

\section{Metode Analisis dan Rancangan Pengujian Hipotesis}

Pengujian hipotesis dilakukan dengan metode analisis statistik deskriptif dan regresi linear berganda. sebelumnya dilakukan uji asumsi klasik terlebih dahulu. Uji asumsi klasik terdiri dari uji normalitas, uji multikolieritas, uji heterokedastisitas, dan uji autokorelasi.

\section{Hasil Dan Pembahasan Statistik Deskripsi}

Pengujian statistik deskriptif bertujuan untuk mengetahui nilai rata-rata, nilai maksimum, nilai minimum, dan standar deviasi. Hasil analisis statistik deskriptif dapat dilihat pada tabel 3. 
Tabel 3

Hasil analisis statistic

\begin{tabular}{|l|c|r|r|r|r|}
\hline & \multicolumn{1}{|c|}{$\mathbf{N}$} & \multicolumn{1}{c|}{ Minimum } & \multicolumn{1}{c|}{ Maximum } & \multicolumn{1}{c|}{ Mean } & \multicolumn{1}{c|}{ Std. Deviastion } \\
\hline ROA & 62 & -.2013 & .1240 & .00519 & .0453115 \\
\hline IC & 62 & .1673 & 11.7138 & 2.835541 & 2.2467287 \\
\hline FDR & 62 & .6944 & 1.5777 & .904639 & .1318439 \\
\hline Valid N (listwise) & 62 & & & & \\
\hline
\end{tabular}

Sumber: Data diolah 2019

Berdasarkan tabel 3 terlihat bahwa variabel dependen yaitu ROA memiliki nilai minimum yaitu sebesar $-0.2013(-20.13 \%)$, nilai maksimum sebesar $0.1240(12.4 \%)$ dan nilai rata-rata ROA sebesar $0.005198(0.5198 \%)$. Hal ini berarti bahwa rata-rata tingkat pengembalian aset perbankan syariah selama tahun 2014-2018 sebesar $0.5198 \%$. variabel ini memiliki standar deviasi sebesar 0.0453115 , yang berarti bahwa variabel ini memiliki data terdistribusi secara menyebar.

Pada variabel Intellectual capital memiliki nilai minimum sebesar 0.1673 , nilai maksimum sebesar 11.7138 dan nilai rata-rata sebesar 2.835541 . Nilai rata-rata tersebut menunjukkan bahwa nilai Intellectual capital perbankan syariah tahun 2014-2018 memiliki peringkat good performers menurut standar skor kinerja oleh Ulum (2008) karena nilainya memiliki skor antara 2.00-2.99. Variabel ini memiliki data terdistribusi secara menyebar dikarenakan nilai rata-ratanya yang lebih besar dari standar deviasi, yaitu sebesar 2.2467287.

Variabel FDR memiliki nilai minimum sebesar 0.6944 (69.44\%), nilai maksimum sebesar 1.5777 (157\%) dan nilai rata-rata sebesar 0.904639 (90.4\%). Nilai minimum dan maksimum tersebut menunjukkan bahwa masih ada perusahan perbankan syariah yang melewati batas bawah dan batas atas dalam memberikan pembiayaan sesuai dengan peraturan Bank Indonesia yaitu antara 78\%-100\%. Nilai standar deviasinya yaitu sebesar 0.1318439. Variabel ini memiliki data terdistribusi secara menyebar dikarenakan nilai rata-ratanya yang lebih besar dari standar deviasi.

Variabel NPF memiliki nilai minimum sebesar $0.00(0 \%)$, nilai maksimum sebesar 0.4399 (43.99\%) dan nilai rata-rata sebesar $0.055647(5.5647 \%)$. Nilai tersebut menunjukkan bahwasanya ada beberapa perbankan syariah yang melewati batas pembiayaan bermasalah ketetapan Bank Indonesia yaitu dibawah 5\%. Variabel ini memiliki data terdistribusi secara menyebar dikarenakan nilai rata-ratanya yang lebih besar dari standar deviasi, yaitu sebesar 0.0739147

\section{Uji Normalitas}

Uji normalitas merupakan "tahap awal dalam melakukan analisis data. Pengujian normalitas bertujuan untuk mengetahui apakah persamaan regresi berdistribusi normal atau mendekati normal (Ghozali, 2013:160). Penelitian ini menggunakan Kolmogorov- Smirnov Test ,bilamana nilai signifikan $>0,05$ maka data tersebut berdistribusi normal. Sedangkan bila nilai signifikannya $<0,05$ memiliki arti bahwa data tidak normal". Hasil pengujian normalitas data dapat dilihat pada tabel dibawah ini

\section{Tabel 4}

Uji Normalitas

One-Sample Kolmogorov-Smirnov Test

\begin{tabular}{|ll|r|}
\hline & & \multicolumn{1}{|c|}{$\begin{array}{c}\text { Unstandardiz } \\
\text { ed Residual }\end{array}$} \\
\hline $\mathrm{N}$ & & 62 \\
Normal Parameters ${ }^{\mathrm{a}, \mathrm{b}}$ & Mean & .0000000 \\
& Std. Dev iation & 1.61655138 \\
Most Extreme & Absolute & .150 \\
Diff erences & Positive & .150 \\
& Negativ e & -.097 \\
Kolmogorov-Smirnov Z & & 1.182 \\
Asy mp. Sig. (2-tailed) & & .122 \\
\hline
\end{tabular}

a. Test distribution is Norm
al. b. Calculated from data.

Berdasarkan tabel output SPPS tersebut, diketahui bahwa nilai signifikansi Asymp.Sig (2tailed) sebesar 0.122 lebih besar dari 0,05. Maka sesuai dengan dasar pengambilan keputusan dalam uji normalitas kolmogrov-smirnov, dapat disimpulkan 
bahwa data berdistribusi normal. Dengan demikian, asumsi atas persyaratan normalitas dalam model regresi sudah terpenuhi.

\section{Uji Multikoliniearitas}

Uji multikolinearitas menurut Ghozali (2013) digunakan untuk menguji apakah pada model regresi ditemukan adanya korelasi antar variabel independen. Pada model regresi yang baik, seharusnya tidak terdapat korelasi antar variabel independen. mengatakan bahwa cara yang dapat digunakan untuk menguji ada tidaknya korelasi antar variabel independen ialah dengan melihat nilai tolerance dan lawannya, Variance Inflaction Factor (VIF). Kedua ukuran ini menunjukkan setiap variabel independen manakah yang dijelaskan oleh variabel lainnya. Nilai yang dipakai untuk menunjukkan adanya multikolonieritas ialah nilai tolerance $\leq 0,10$ atau sama dengan nilai VIF $\geq 10$. Hasil pengujian multikolonieritas dapat dilihat pada tabel 4.3

\section{Tabel 5}

Uji Multikolonieritas

\begin{tabular}{|c|c|c|c|c|c|c|c|}
\hline \multirow[t]{2}{*}{ Model } & \multirow{2}{*}{$\begin{array}{c}\begin{array}{c}\text { Unstandardized Coeff } \\
\text { icients }\end{array} \\
\text { B }\end{array}$} & \multirow{2}{*}{$\begin{array}{l}\begin{array}{c}\text { Standardized Coeff } \\
\text { icients }\end{array} \\
\text { Std. Error }\end{array}$} & \multirow{2}{*}{$\frac{\mathrm{t}}{\text { Beta }}$} & \multicolumn{2}{|c|}{ Sig. } & \multicolumn{2}{|c|}{$\begin{array}{l}\text { Collinearity } \\
\text { Statistics }\end{array}$} \\
\hline & & & & & & Tolerance & VIF \\
\hline $\begin{array}{ll}1 & \text { (Constant) IC } \\
& \text { FDR NPF }\end{array}$ & $\begin{array}{l}-1.268 \\
.042 \\
.043 \\
-.385\end{array}$ & $\begin{array}{l}1.525 \\
.111 \\
.018 \\
.032\end{array}$ & $\begin{array}{l}.027 \\
.184 \\
-.908\end{array}$ & $\begin{array}{c}-.832 \\
.384 \\
2.450 \\
- \\
12.160\end{array}$ & $\begin{array}{l}.409 \\
.703 \\
.017 \\
.000\end{array}$ & $\begin{array}{l}.956 \\
.818 \\
.824\end{array}$ & $\begin{array}{l}1.046 \\
1.223 \\
1.214\end{array}$ \\
\hline
\end{tabular}

Berdasarkan tabel output "Coefficients" diketahui bahwa nilai Tolerance untuk variabel IC (X1) sebesar 0.956, variabel FDR (X2) sebesar 0.818, dan variabel NPF (X3) sebesar 0.824 lebih besar dari 0,10 . Sementara, nilai VIF untuk variabel IC (X1) sebesar 1.046, variabel FDR (X2) sebesar 1.223, dan variabel NPF (X3) sebesar 1.214 lebih kecil dari 10,00. Maka mengacu pada dasar pengambilan keputusan dalam uji multikolinearitas dapat disimpulkan bahwa tidak terjadi gejala multikolinearitas dalam model regresi.

\section{Uji Autokorelasi}

Uji autokolerasi memiliki tujuan untuk menguji apakah dalam suatu model regresi linear terdapat korelasi antara kesalahan pengganggu pada periode $t$ dengan kesalahan pengganggu pada periode t-1 (sebelumnya) dengan menggunakan uji DurbinWatson (Ghozali, 2013;175). Tabel 4.4 berikut ini menunjukkan hasil pengujian normalitas menggunakan Durbin-Watson.

Tabel 6

Uji Statistik Autokorelasi

\begin{tabular}{|c|c|c|c|c|c|}
\hline Model & $\mathrm{R}$ & $\mathrm{R}$ Square & Adjusted R Square & St d. Error of the Estimate & Durbin- Wat son \\
\hline 1 & $.857 \mathrm{a}$ & .734 & .720 & 1.65783 & 1.842 \\
\hline
\end{tabular}

a. Predictors: (Constant), NPF, IC, FDR

b. Dependent Variable: ROA

Berdasarkan hasil uji autokorelasi diatas, diketahui bahwa nilai Durbin Watson (d) sebesar 1.842 lebih besar dari batas atas (dU) yakni 1,69180 dan kurang dari (4-dU) 4-1,69180 =2.3082. Maka sebagaimana dasar pengambilan keputusan dalam uji durbin watson, dapat disimpulkan bahwa tidak terdapat masalah atau gejala autokorelasi. Dengan demikian maka analisis regresi linear berganda untuk uji hipotesis penelitian dapat dilanjutkan.

\section{Uji Heteroskedastisitas}

Uji heteroskedastisitas bertujuan untuk menguji apakah dalam model regresi terjadi ketidaksamaan varian dari satu pengamatan ke 
pengamatan yang lain. Jika varian dari residual satu pengamatan ke pengamatan lain tetap, maka disebut homoskedastisitas dan jika berbeda disebut heteroskedastisitas. Model regresi yang baik ialah yang tidak muncul heteroskedastisitas (Ghozali,2013:139). Metode yang digunakan dalam penelitian ini ialah menggunakan Uji Glejser. Uji
Glejser yaitu meregres nilai absolut residual terhadap variabel independen. Jika variabel independen signifikan secara statistic mempengaruhi variabel dependen, maka ada indikasi terhadinya heteroskedastisitas. Hasil uji heteroskedastisitas dengan uji Glejser dapat dilihat pada tabel berikut

Tabel 7

Uji Heteroskedastisitas

\begin{tabular}{llrrrrr}
\hline \multirow{2}{*}{ Model } & \multicolumn{2}{c}{ Unstandardized Coefficients } & \multicolumn{2}{c}{ Standardized Coefficients } & & \\
\cline { 2 - 5 } & \multicolumn{2}{c}{ B } & Std. Error & Beta & S & Sig. \\
\hline 1 & (Constant) & .647 & .028 & & .629 & .532 \\
& IC & .006 & .075 & .011 & .087 & .931 \\
& FDR & .021 & .012 & .246 & 1.742 & .087 \\
NPF & -.016 & .021 & -.106 & -.755 & .453 \\
\hline
\end{tabular}

Berdasarkan hasil pengujian pada table 4.5 dapat dilihat bahwa "IC, FDR dan NPF mempunyai nilai signifikansi lebih besar dari 0.05. Hal ini menunjukkan bahwasanya tidak terjadi gejala heteroskedastisitas dalam penelitian ini”.
Hasil Pengujian Hipotesis

\section{Analisis Regresi Linear Berganda}

Berdasarkan hasil perhitungan statistik seperti yang terlihat pada table 8 maka diperoleh persamaan regresi linear berganda sebagai berikut:

$$
\mathrm{Y}=-\mathbf{1 . 2 6 8}+0.042 \mathrm{X} 1+0.043 \mathrm{X} 2-0.385 \mathrm{X} 3+\mathrm{e}
$$

Tabel 8

Pengaruh Variabel Independen terhadap Variabel Dependen

\begin{tabular}{|c|c|c|c|c|c|c|c|}
\hline \multirow[t]{2}{*}{ Model } & \multicolumn{2}{|c|}{ Unstandardized Coefficients } & \multirow{2}{*}{$\begin{array}{c}\begin{array}{c}\text { Standardized } \\
\text { Coefficients }\end{array} \\
\text { Beta }\end{array}$} & \multirow[t]{2}{*}{$\mathrm{t}$} & \multirow[t]{2}{*}{ Sig. } & \multicolumn{2}{|c|}{$\begin{array}{c}\text { Colinearity } \\
\text { Statistics }\end{array}$} \\
\hline & B & Std. Error & & & & Tolerance & VIF \\
\hline (Constant) & -1.268 & 1.525 & & -.832 & .409 & & \\
\hline IC & .042 & .111 & .027 & .384 & .703 & .956 & 1.046 \\
\hline FDR & .043 & .018 & .184 & 2.450 & .017 & .818 & 1.223 \\
\hline NPF & -.385 & .032 & -.908 & -12.160 & .000 & .824 & 1.214 \\
\hline
\end{tabular}

a. Dependent Variable: ROA

\section{Uji Signifikansi Simultan (Uji Statistik F)}

Uji statistik $F$ pada dasarnya menunjukkan apakah semua variabel bebas yang dimasukkan dalam model mempunyai pengaruh secara bersama-sama terhadap variabel dependen (Ghozali, 2013;98). Hasil uji simultan dapat dilihat pada tabel 9

Tabel 9

Uji Statistik F

\begin{tabular}{llrrrrr}
\hline \multicolumn{1}{c}{ Model } & Sum of Squares & Df & Mean Square & F & Sig \\
\hline 1 & Regression & 439.725 & 3 & 146.575 & 53.331 & $.000^{\mathrm{a}}$ \\
& Residual & 159.408 & 58 & 2.748 & & \\
Total & 599.133 & 61 & & \\
\hline
\end{tabular}

Berdasarkan tabel output SPSS diatas, diketahui bahwa nilai Sig. Adalah sebesar 0,000. Karena nilai Sig. 0,000 $<0,05$, maka sesuai dengan dasar pengambilan keputusan dalam uji $\mathrm{F}$ dapat disimpulkan bahwa hipotesis diterima, atau dengan 
kata lain IC (X1), FDR (X2), dan NPF (X3) secara simultan berpengaruh terhadap profitabilitas.

\section{Uji Signifikansi Individual (Uji Statistik t)}

Pengujian hipotesis uji $\mathrm{t}$ dilakukan untuk menyelidiki lebih lanjut manakah diantara tiga variabel independen yang berpengaruh signifikan terhadap tingkat profitabilitas. Uji statistik t dilakukan dengan melihat nilai signifikansi yang diperoleh masing-masing variabel.

Tabel 10

Uji Statistik t

\begin{tabular}{|c|c|c|c|c|c|c|c|c|}
\hline \multirow{2}{*}{\multicolumn{2}{|c|}{ Model }} & \multicolumn{2}{|c|}{ Unstandardized Coefficients } & \multirow{2}{*}{$\begin{array}{c}\text { Standardized } \\
\text { Coefficients } \\
\text { Beta }\end{array}$} & \multirow[t]{2}{*}{$\mathrm{t}$} & \multirow[t]{2}{*}{ Sig. } & \multicolumn{2}{|c|}{$\begin{array}{l}\text { Colinearity } \\
\text { Statistics }\end{array}$} \\
\hline & & B & Std. Error & & & & Tolerance & VIF \\
\hline \multirow[t]{4}{*}{1} & (Constant) & -1.268 & 1.525 & & -.832 & .409 & & \\
\hline & IC & .042 & .111 & .027 & .384 & .703 & .956 & 1.046 \\
\hline & FDR & .043 & .018 & .184 & 2.450 & .017 & .818 & 1.223 \\
\hline & NPF & -.385 & .032 & -.908 & -12.160 & .000 & .824 & 1.214 \\
\hline
\end{tabular}

a. Dependent Variable: ROA

1. Variabel IC (X1) memiliki nilai t sebesar 0.384 yang berarti bahwa IC berpengaruh secara positif terhadap profitabilitas. Kemudian menunjukan angka signifikansi sebesar 0.703 . Nilai signifikansi tersebut lebih besar dari 0,05. Hal ini berarti bahwa IC(X1) tidak memiliki pengaruh yang signifikan terhadap profitabilitas perbankan syariah.

2. Variabel FDR (X2) memiliki nilai t sebesar 2.450 yang berarti bahwa FDR berpengaruh secara positif terhadap profitabilitas. Kemudian menunjukan nilai signifikansi sebesar 0,017. Nilai signifikansi tersebut lebih kecilr dari 0,05. Hal ini berarti bahwa FDR (X2) memiliki pengaruh yang signifikan terhadap profitabilitas perbankan syariah.

3. Variabel NPF (X3) memiliki nilai t sebesar 12.160 yang berarti bahwa NPF berpengaruh secara negatif profitabilitas. Kemudian menunjukan nilai signifikansi sebesar 0.000 . Nilai signifikansi tersebut jauh lebih kecil dari signifikansi $5 \%$ atau 0,05 . Hal ini berarti bahwa NPF (X3) memiliki pengaruh yang signifikan terhadap profitabilitas bank syariah.

\section{Koefisien Determinasi}

Koefisien determinasi (R2) mengukur besarnya persentase variasi variabel dependen yang dapat dijelaskan oleh variabel independen. Nilai koefisien determinasi ialah antara nol dan satu. Nilai R2 yang kecil berarti bahwa kemampuan variabel independen dalam menerangkan variabel dependen sangat terbatas. Nilai yang mendekati satu berarti bahwa variabel independen memberikan hampir semua informasi yang dibutuhkan untuk memprediksi variasi variabel dependen (Ghozali, 2013).

Tabel 9

Uji Statistik F

\begin{tabular}{|c|c|c|c|c|c|}
\hline Model & $\mathrm{R}$ & R Square & Adjusted R Square & St d. Error of the Estimate & Durbin- Wat son \\
\hline 1 & $.857^{\mathrm{a}}$ & .734 & .720 & 1.65783 & 1.842 \\
\hline
\end{tabular}

a. Predictors: (Const ant ), NPF, IC, FDR

b. Dependent Variable: ROA

Berdasarkan tabel output SPSS "Model Summary diatas, diketahui bahwa nilai koefisien determinasi (Adjusted R Square) adalah sebesar 0.734 atau sama dengan $73.4 \%$. Angka tersebut mengandung arti bahwa variabel IC (X1), FDR (X2) dan NPF (X3) secara bersama-sama berpengaruh terhadap variabel profitabilitas (Y) sebesar 73.4\%. Sedangkan sisanya dipengaruhi oleh variabel lain diluar persamaan regresi ini atau variabel yang tidak diteliti. 


\section{Pembahasan Hasil Penelitian}

\section{Pengaruh Intellectual capital, Financing to deposit} ratio dan Non performing financing Terhadap Profitabilitas

Berdasarkan hasil pengujian statistik $\mathrm{F}$ diperoleh nilai signifikansi sebesar 0,000 yang berarti bahwa variabel independen, yaitu pengaruh Intellectual capital, Financing to deposit ratio dan Non performing financing secara simultan berpengaruh signifikan terhadap variabel dependen, yaitu profitabilitas perbankan syariah di Indonesia tahun 2014-2018, sehingga dapat disimpulkan bahwa hipotesis pertama $(\mathrm{H} 1)$ diterima.

\section{Pengaruh Intellectual capital Terhadap Profitabilitas}

Hasil dari pengujian hipotesis menunjukkan bahwa variabel Intellectual capital mempunyai nilai $\mathrm{t}$ sebesar 0.384 yang berarti berpengaruh positif. Hal itu menunjukkan bahwa semakin besar nilai intellectual capital maka akan semakin besar profitabilitas (ROA). Selain itu, variabel intellectual capital memiliki tingkat signifikansi $0,703>0,05$ yang berarti tidak signifikan. Hal tersebut menunjukkan bahwa Intellectual capital tidak berpengaruh secara signifikan terhadap profitabilitas (ROA), sehingga dapat disimpulkan bahwa hipotesis kedua (H2) ditolak.

Hasil penelitian ini sejalan dengan beberapa penelitian yang dilakukan oleh Basuki dan Sianipar (2009), Firrer dan Williams (2003) dalam Bustamam, Dhenni Aditia (2016), Setyarini Santosa (2012) Ulfa Ikhwazahmi (2014) yang mengatakan bahwasanya intellectual capital tidak memiliki pengaruh terhadap profitabilitas. Hal tersebut menunjukkan bahwasanya perbankan syariah di Indonesia tahun 2014-2018 masih kurang memaksimalkan intellectual capital untuk meningkatkan profitabilitas perusahaan.

\section{Pengaruh Financing to deposit ratio Terhadap Profitabilitas}

Hasil dari pengujian hipotesis menunjukkan bahwa Financing to deposit ratio mempunyai nilai t sebesar 2.450 yang berarti berpengaruh positif dan menunjukkan bahwa semakin besar nilai Financing to deposit ratio maka akan semakin besar pula profitabilitas (ROA). Variabel Financing to deposit ratio juga memiliki tingkat signifikansi $0,017<0,05$ yang berarti berpengaruh signifikan. Hal tersebut menunjukkan bahwa Financing to deposit ratio berpengaruh signifikan terhadap profitabilitas (ROA), sehingga dapat disimpulkan bahwa hipotesis ketiga (H3) diterima.

Hasil penelitian ini mendukung penelitian yang dilakukan oleh Slamet Riyadi, Agung Yulianto (2014), Muhammad Yusuf, Surachman Surjaatmadja (2018) dan Dhian Dayinta (2012) yang mengatakan bahwasanya Financing to deposit ratio memiliki pengaruh terhadap profitabilitas. Hal ini terjadi karena ketika penyaluran dana ke masyarakat tinggi maka akan mendapat pengembalian yang tinggi pula dan akan berdampak pada laba yang diperoleh bank.

\section{Pengaruh Non performing financing Terhadap Profitabilitas}

Hasil dari pengujian hipotesis menunjukkan bahwa Non performing financing mempunyai nilai $\mathrm{t}$ sebesar -12.160 yang berarti berpengaruh negatif dan menunjukkan bahwa nilai Non performing financing berbanding terbalik dengan profitabilitas (ROA), semakin kecil Non performing financing maka akan semakin besar profitabilitas (ROA). Selain itu variabel ini memiliki tingkat signifikansi $0,000<0,05$ yang berarti berpengaruh signifikan. Hal tersebut menunjukkan bahwa Non performing financing berpengaruh signifikan terhadap profitabilitas (ROA), sehingga dapat disimpulkan bahwa hipotesis keempat (H4) diterima.

Ada beberapa hasil penelitian terdahulu yang mendukung hasil penelitian ini, seperti penelitian yang dilakukan oleh Fitri Zulfiah (2013) dan Joni Susilowibowo (2013) Suryanto (2017) yang mengatakan bahwasanya Financing to deposit ratio memiliki pengaruh terhadap profitabilitas.

NPF mencerminkan risiko pembiayaan, semakin tinggi NPF mengakibatkan semakin tinggi risiko pembiayaan bermasalah yang berpotensi akan menurunkan keuntungan yang diperoleh. Demikian sebaliknya, semakin rendah NPF, maka ROA akan semakin tinggi ataupun sebaliknya jika NPF tinggi maka akan membuat ROA semakin menurun.

\section{Kesimpulan Keterbatasan dan Saran 5.1 Kesimpulan}

Berdasarkan hasil penelitian yang dijelaskan sebelumnya, dapat diambil kesimpulan bahwa:

1. Intellectual capital, Financing to deposit ratio dan Non performing financing secara simultan berpengaruh terhadap profitabilitas 
perbankan syariah di Indonesia tahun 2014-2018

2. Variabel Intellectual capital secara parsial tidak memiliki pengaruh yang signifikan terhadap profitabilitas perbankan syariah di Indonesia tahun 2014-2018.

3. Variabel Financing to deposit ratio secara parsial berpengaruh signifikan terhadap profitabilitas perbankan syariah di Indonesia tahun 2014-2018.

4. Variabel Non performing financing secara parsial berpengaruh signifikan terhadap profitabilitas perbankan syariah di Indonesia tahun 2014-2018.

\subsection{Keterbatasan}

Penelitian ini memiliki keterbasan yang dapat dijadikan bahan pertimbangan untuk peneliti pada masa yang akan datang sehingga diperoleh hasil yang lebih baik, keterbatasan dalam penelitian ini yaitu terbatasnya referensi dan metode pengukuran Intellectual capital pada perbankan syariah.

\subsection{Saran}

1. Bagi perbankan syariah diharapkan mampu menjaga rasio FDR dalam rentang $78 \%$ sampai dengan 100\% dan rasio NPF dibawah 5\% sesuai dengan peraturan Bank Indonesia.

2. Peneliti berikutnya diharapkan dapat memperluas objek penelitian seperti UUS dan BPRS.

3. Peneliti berikutnya juga diharapkan menambah variabel lain seperti variabel non keuangan

\section{Daftar Pustaka}

Ascarya, Diana Yumanita. (2005). Bank Syariah (Gambaran Umum). Jakarta: Pusat Pendidikan dan Studi Kebanksentralan (PPSK)

Asiah, Antung Noor. (2014). Pengaruh Intellectual Capital TerhadapProfitabilitas (Studi Empiris pada Lembaga Keuangan). Jurnal Spread. Vol. 4 No. 1.

Al-Musali, M. A. K., \& Ismail, K. N. I. K. (2015). Intellectual Capital and its Effect on Financial Performance of Banks: Evidence from Saudi Arabia. Procedia - Social and Behavioral Sciences,164 (August) , 201207 https://doi.org/10.1016/j.sbspro.2014.11.068
Authors, F. (2011). Intellectual capital \pm does it create or destroy value? https://doi.org/10.1108/13683040410524757

Bank Indonesia. Pengembangan-EkonomiKeuangan- Syariah-untuk-MendukungPertumbuhan- Ekonomi-Berkelanjutan. Melalui https://www.bi.go.id. Diakses 5 Maret 2019

Chou, T.-K., \& Buchdadi, A. D. (2016). Bank Performance and Its Underlying Factors: A Study of Rural Banks in Indonesia. Accounting and Finance Research, 5(3), 55-63. https://doi.org/10.5430/afr.v5n3p55

Dendawijaya, Lukman. (2009). Manajemen Perbankan. Jakarta: Ghalia Indonesia.

Fitri, Joni. (2013). Pengaruh Inflasi, BI rate,Capital Adequaty Ratio (CAR), Non Performing Financing (NPF), Biaya Operasional dan Pendapatan Operasional (BOPO) terhadap Pendapatan Bank Umum Syariah Periode 2008-2012. Jurnal. Universitas Negeri Surabaya.

Ghozali, Imam. (2013). Aplikasi Analisis Multivariate dengan Program IBM SPSS21. Semarang: Undip.

Halim, A., Basri, H., \& Faisal. (2016). Pengaruh Intellectual Capital Terhadap Profitabilitas Dan Dampaknya Terhadap Harga Saham Perusahaan Sektor Keuangan Yang Terdaftar Di Bursa Efek Indonesia (BEI). Jurnal Bisnis Dan Ekonomi (JBE), 23(2), 124-141.

Indriantoro, Nur., dan Supomo, Bambang. (2013). Metodologi Penelitian Bisnis Untuk Akuntansi \& Manajemen. Yogyakarta: BPFE.

Kasmir. (2014). Bank dan Lembaga Keuangan Lainnya. Edisi Revisi, Cetakan keempatbelas, PT. RajaGrafindo Persada, Jakarta.

Mudjarat, Kuncoro \& Suharjonoo (2002). Manajemen Perbankan. Yogyakarta: BPFE.

Muhammad. (2005). Manajemen Bank Syariah. Yogyakarta : UPP AMP YKPN

Otoritas Jasa Keuangan. Roadmap Pengembangan Keuangan Syariah Indonesia 2017-2019. Melalui https://www.ojk.go.id/. Diakses 24 Februari 2019.

OJK. (2017). Statistik Perbankan Syariah J anuari 2017. Retrieved March 17, 2017, from 
www.ojk.go.id

OJK. No.15/POJK.03/2017 tentang Penetapan Status dan Tindak Lanjut Pengawasan Bank Umum. Diakses 1 Agustus 2019

Prasetyo, R. Y. (2016). ( Studi pada Perusahaan Properti dan Real Estate yang Terdaftar pada Bursa Efek Indonesia Periode 2011-2013 ). Jurnal Administrasi Bisnis (JAB)|Vol., 30(1).

Republik Indonesia. Undang-Undang Nomor 21 Tahun 2008 Tentang Perbankan Syariah.

Republik Indonesia. Undang-Undang Nomor 10 Tahun 1998 Tentang Perbankan.

Rivai, Veithzal dan Arviyan Arifin. (2010). Islamic Banking Sebuah Teori, Konsep, dan Aplikasi. Jakarta: Bumi Aksara

Sangia, Arviqa. (2012). "Analisis Pengaruh CAR, FDR, BOPO, dan NCOM terhadap Profitabilitas (ROA) Bank Umum Syariah di Indonesia (Studi pada Bank Umum Syariah Periode 2008- 2011)". Skripsi, Universitas Diponegoro Semarang

Sekaran, Uma. (2014). Metodologi Penelitian untuk Bisnis (Research Methods for Business). Buku 1 Edisi 4. Jakrta: Salemba Empat.

Sekaran, Uma., \& Bougie. R. 2013. Research Methods for Business: A Skill-Building Approach. Sixth Edition. USA: Wiley.

Suryanto. (2017). Determinants of Profitability in Commercial Banks of Indonesia an Empirical Study. International Journal of Business and Management Review, 5(1), 111. Retrieved from http://www.eajournals.org/wpcontent/uploads/Determinants-of-Profitabilityin- Commercial-Banks-of-Indonesia-anEmpirical- Study.pdf

Soetedjo, Soegeng dan Safrina Mursida. (2014). Pengaruh Intellectual Capital terhadap Kinerja Keuangan pada Perusahaan Perbankan. SNA XVII. Mataram.

Ulum, Ihyaul. (2009). Intellectual Capital: Konsep dan Kajian Empiris, Grahallmu, Yogyakarta

Ulum, Ihyaul. (2015). Intellectual Capital: Model Pengukuran, Framework Pengungkapan dan Kinerja Organisasi. UMM Press, Malang

Wardana, R. I. P., \& Widyarti, E. T. (2015). ( Studi
Kasus Pada Bank Umum Syariah di Indonesia Periode 2011-2014 ), 4, 1-12.

Wijaya, Sheleen. "Pengaruh Organizational Learning Terhadap Competitive Advantage Melalui Accounting Information System Pada Perusahaan Manufaktur Terbuka." Business Accounting Review 3.2 (2015): 61-70. 